Jurnal Pemberdayaan: Publikasi Hasil Pengabdian kepada Masyarakat

Vol. 2, No. 3, Desember 2018, Hal. 513-518

ISSN: 2088 4559; e-ISSN: XXXX-XXXX

DOI:

\title{
PEMBERDAYAAN MASYARAKAT DUSUN SUMBERAN RT 11, NGESTIHARJO, KASIHAN, BANTUL DALAM PROGRAM PEDULI LINGKUNGAN
}

\author{
Sulistiyono $^{1}$, Septia' Liesa $^{2}$ \\ ${ }^{1,2}$ Universitas Ahmad Dahlan, Jalan Kapas, No 9, Semaki Yogyakarta 55166 \\ Email: roni.sulistiyono@pbsi.uad.ac.id
}

\begin{abstract}
ABSTRAK
Salah satu permasalahan yang ada di masyarakat RT 11 Sumberan, Ngestiharjo, Kasihan, Bantul yaitu banyaknya botol plastik air mineral yang tidak dimanfaatkan dengan baik. Maka program KKN UAD difokuskan pada pemanfaatan limbah botol plastik. Program ini bertujuan memberdayakan masyarakat RT 11 Sumberan Ngestiharjo dalam program Peduli Lingkungan. Metode pelaksanaan program KKN meliputi: pelatihan masyarakat dan praktik langsung. Dampak dari kegiatan KKN ini adalah, (1) tercipta kesadaran masyarakat sasaran tentang pentingnya menjaga lingkungan, (2) peningkatan pengetahuan masyarakat dalam mengolah sampah, 3) masyarakat terampil membuat karya kreatif dari botol plastik bekas.
\end{abstract}

Kata kunci : Pemberdayaan, Sumberan RT 11 Ngestiharjo, Peduli Lingkungan

\begin{abstract}
One of the problems in the RT 11 Sumberan community, Ngestiharjo, Kasihan, Bantul, is that there are many plastic bottles of mineral water that are not used properly. So the UAD KKN program is focused on utilizing plastic bottle waste. The program aims to empower the community of RT 11 Sumberan Ngestiharjo in the Environmental Care program. The methods for implementing the KKN program include: community training and direct practice. The impact of this KKN activity is, (1) creating awareness of the target community about the importance of protecting the environment, (2) increasing community knowledge in processing waste, 3) the community is skilled at making creative works from used plastic bottles.
\end{abstract}

Keywords: Empowerment, Resources RT 11 Ngestiharjo, Caring for the Environment 


\section{PENDAHULUAN}

Sumberan merupakan salah satu lingkungan di Kecamatan Kasihan, Bantul. Dusun Sumberan memiliki 13 RT. Akses jalannya cukup mudah dilalui oleh kendaraan darat roda dua maupun roda empat. Beberapa permasalahan yang ditemukan di sumberan RT 11 adalah: 1). Kurangnya pengetahuan masyarakat dalam memilah sampah organik dan anorganik, 3) Kurangnya keterampilan masyarakat dalam memanfaatkan sampah yang masih dapat digunakan.

Menurut Syafrudin (2004), salah satu alternatif yang bisa dilakukan adalah melaksanakan program pengelolaan sampah berbasis masyarakat, seperti meminimalisasi limbah dan melaksanakan 5 R (Reuse, Recycling, Recovery, Replacing dan Refilling). Pemanfaatan limbah botol plastik dengan cara membuat hidroponik. Hidroponik dapat didefinisikan secara sederhana sebagai cara budidaya tanaman tanpa menggunakan media tanah, tetapi menggunakan larutan hara yang diberikan dengan dukungan mekanis dari media tanam seperti kerikil, pasir, sabut kelapa, rockwool dan sebagainya, jadi dalam budidaya tanaman secara hidroponik, tanaman memperoleh unsur hara dari larutan yang mengandung semua unsur hara esensial yang diperlukan tanaman. Larutan tersebut diberikan dengan cara digenangkan atau dialirkan ke media tanam hidroponik sebagai tempat berkembangnya akar (Iqbal, 2017).

Berdasarkan permasalahan tersebut, maka ditetapkan tujuan program KKN ini adalah memberdayakan masyarakat Sumberan RT 11 Ngestiharjo, Kasihan, Bantul dalam kepedulian lingkungan.

\section{METODE PELAKSANAAN}

Untuk mencapai tujuan yang diharapkan, program KKN di Sumberan RT 11 dilakukan dengan pemberdayaan masyarakat melalui pelatihan masyarakat dan praktek langsung. Ringkasan metode pelaksanaan beserta jam kerja efektif mahasiswa (JKEM) tersaji pada tabel 1 . 
Tabel 1. Metode, Kegiatan, JKEM dan keterlibatan mahasiswa

\begin{tabular}{|l|l|l|c|c|}
\hline No & Metode & Kegiatan & JKEM & $\begin{array}{l}\text { Jumlah } \\
\text { mahasiswa } \\
\text { yang terlibat }\end{array}$ \\
\hline 1 & $\begin{array}{l}\text { Pelatihan } \\
\text { masyarakat }\end{array}$ & $\begin{array}{l}\text { Menyelenggarakan penyuluhan } \\
\text { pemanfaatan limbah } \\
\text { botol plastik }\end{array}$ & $2 \times 1$ jam & 3 \\
\hline 2 & Difusi iptek & $\begin{array}{l}\text { Menyelenggarakan pelatihan } \\
\text { pembuatan sistem hidroponik }\end{array}$ & $1 \times 3$ jam & 9 \\
\hline 3 & Praktik & $\begin{array}{l}\text { Pelatihan pemilahan botol } \\
\text { plastik sesuai kriteria }\end{array}$ & $1 \times 2$ jam & 4 \\
\cline { 2 - 4 } & $\begin{array}{l}\text { Pelatihan pembuatan hidroponik } \\
\text { dari botol plastik }\end{array}$ & $2 \times 2$ jam & 9 \\
\hline
\end{tabular}

\section{HASIL, PEMBAHASAN DAN DAMPAK}

a) Profil Desa

Pedukuhan II Sumberan Desa Ngestiharjo merupakan salah satu Desa yang ada di Kecamatan Kasihan, Kabupaten Bantul, provinsi Daerah Istimewah Yogyakarta (DIY). Pedukuhan II Sumberan berdiri pada tahun 1965 yang sekarang terdiri dari 13 RT dari penggabungan 4 (empat) kelurahan lama yang masing-masing mempunyai 3 pedukuhan yaitu:

1. Kelurahan Lama Kembang (Pedukuhan I Tambak, Pedukuhan II Sumberan dan Pedukuhan III Soragan)

2. Kelurahan Lama Sutopadan (Pedukuhan IV Cungkuk, Pedukuhan V Kadipiro dan Pedukuhan VIII Janten)

3. Kelurahan Lama Nitipuran (Pedukuhan VI Sonosewu, Pedukuhan VII Jomegatan dan Pedukuhan IX Sonopakis Lor)

4. Kelurahan Lama Onggobayan (Pedukuhan X Sonopakis Kidul, Padukuhan XI Onggobayan , dan Pedukuhan XII Sidorejo)

Pedukuhan II Sumberan Desa Ngestiharjo merupakan sebuah Desa yang berbatasan dengan beberapa Desa/Kelurahan dan Kabupaten antara lain:

1. Sebelah Utara berbatasan dengan Pedukuhan I Tambak 
2. Sebelah Timur berbatasan dengan Pedukuhan III Soragan dan Kelurahan Tegalrejo Kecamatan Tegalrejo Kodya Yogyakarta

3. Sebelah Selatan berbatasan dengan Pedukuhan IV Cungkuk

4. Sebelah Barat berbatasan dengan Desa Banyuraden Kecamatan Gamping Kabupaten Sleman.

Luas wilayah Pedukuhan II Sumberan adalah 39,93 Ha. Wilayah yang digunakan sebagai pemukiman seluas 33,60 Ha, wilayah sawah seluas 2,23 Ha, wilayah Industri seluas 0,70 Ha dan Fasum seluas 3,40 Ha.

Warga Pedukuhan II Sumberan Desa Ngestiharjo RT 11 memiliki berbagai macam mata pencaharian seperti PNS, POLRI, TNI, TANI, Wiraswasta, Dokter, Guru, Buruh, dan Pedagang. Disamping itu, keanekaragaman agama juga di miliki oleh Pedukuhan II Sumberan Desa Ngestiharjo RT 11 ini, diantaranya yaitu agama Islam dan Kristen, dengan mayoritas penduduknya beragama Islam. Walaupun memiliki berbagai macam etnis dan agama toleransi sangat dijunjung tinggi. Warga Pedukuhan II Sumberan Desa Ngestiharjo RT 11 memiliki kegiatan rutin lingkungan yang diadakan setiap bulan, seperti Jalan Sehat setiap minggu kedua, pertemuan PKK setiap pertengahan bulan, dan posyandu yang diadakan pada minggu kedua.

Fasilitas dan aktivitas keagamaan di Pedukuhan II Sumberan Desa Ngestiharjo RT 11, Kecamatan Kasihan, Kabupaten Bantul memiliki Di wilayah Sumberan ini memiliki 6 tempat ibadah yaitu Masjid Al-Ghofur (Rt. 09), Masjid Nur Jihan (Rt.13), Musholla Miftahul huda (Rt.08), Musholla Ar-Raudhoh (Rt.11), Musholla Al-Hijrah (Rt.09), dan Musholla Al-Hikmah (Rt.12). Adapun kegiatan keagamaan rutin khususnya di Mushollah Ar-Raudhoh yaitu majelis pengajian rutin bapak-bapak dan ibu-ibu, dan TPA. Pengajian malam jum'at kliwon, pengajian barjanji selama bulan maulid, dan pengajian mungkasan yang diadakan pada minggu terakhir memasuki bulan maulid, Sedangkan Aktivitas pelayanan kesehatan yang ada : posyandu balita dan lansia tiap bulan sekali.

b) Gambaran Pelaksanaan

Gambar aktivitas mahasiswa KKN UAD dan masyarakat Sumberan RT 11 dalam program peduli lingkungan tersaji pada gambar 1. 


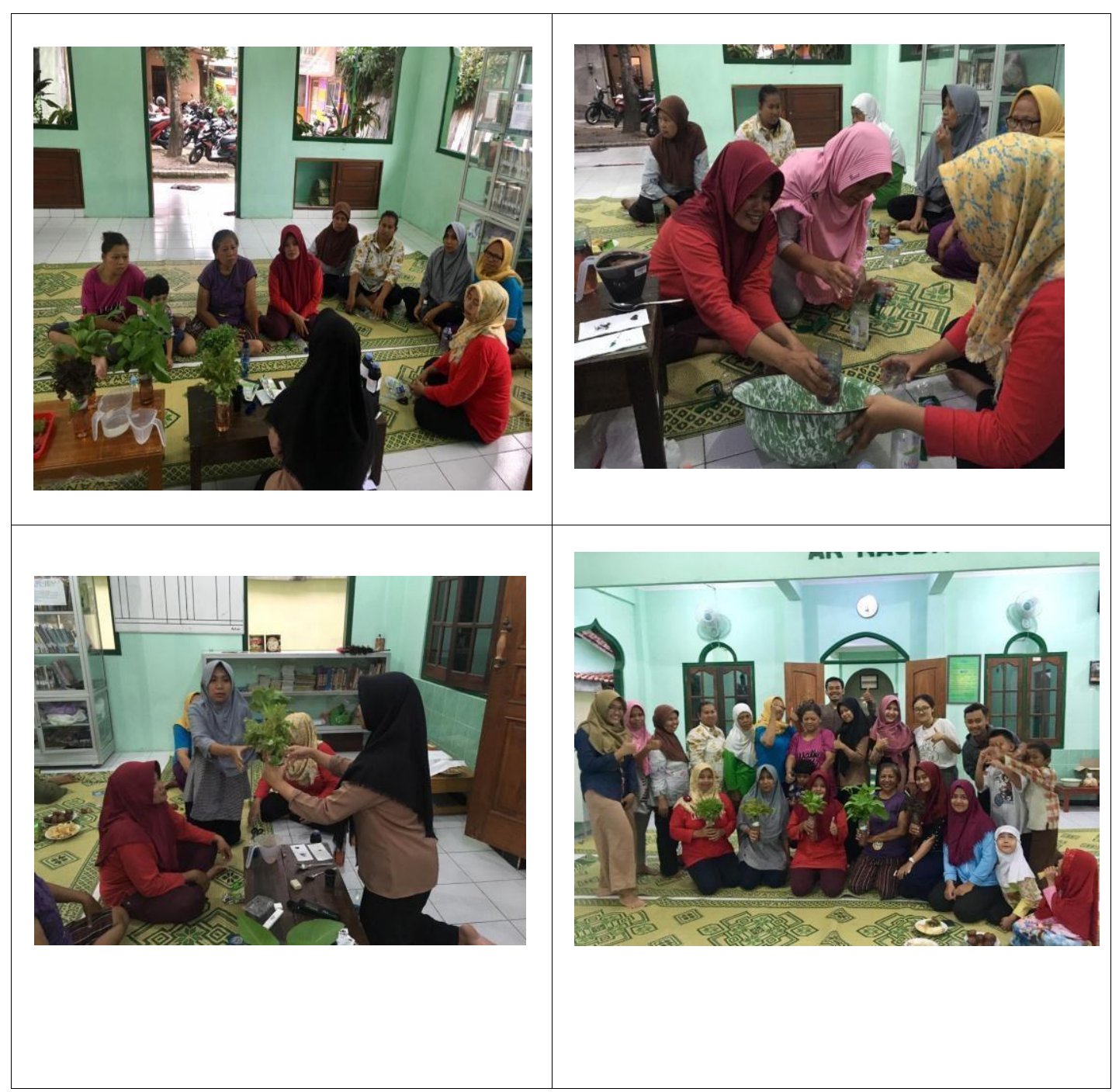

Gambar 1. Aktivitas mahasiswa KKN UAD dan masyarakat Pedukuhan II Sumberan Desa Ngestiharjo RT 11 dalam program peduli lingkungan

Dari Gambar 1 terlihat program KKN di Sumberan RT 11 dapat terlaksana dengan partisipasi masyarakat menggunakan metode yaitu : 1) Pelatihan masyarakat dengan melakukan kegiatan penyuluhan pemanfaatan limbah botol plastik, bahwa adanya potensi dari limbah botol plastik untuk dibuah sebagai tempat media hidroponik. 2) Difusi iptek dengan menyelenggarakan pelatihan pembuatan sistem hidroponik, adapun materi yang dipaparkan meliputi pengetahuan tentang macam-macam sistem hidroponik, nutrisi hidroponik dan jenis tanaman yang dapat ditanam pada sistem hidroponik. 3) Praktik yang dilakukan meliputi : pemilahan botol plastik sesuai kriteria, pelatihan hidroponik meliputi pengenalan alat dan bahan, pembuatan sistem hidroponik menggunakan botol bekas, pembuatan nutrisi hidroponik, dan perawatan hidroponik. 
Adapun dampak dari kegiatan KKN ini adalah : 1) Tercipta kesadaran masyarakat sasaran tentang pentingnya menjaga lingkungan, 2) Peningkatan pengetahuan masyarakat dalam mengelolah sampah, 3) Masyarakat terampil membuat karya kreatif dari botol plastik bekas.

\section{KESIMPULAN}

Program KKN UAD dalam memberdayakan masyarakat Sumberan RT 11 terhadap kepedulian lingkungan telah berjalan dengan baik.

\section{DAFTAR PUSTAKA}

Iqbal, Muhammad. 2017. Simpel Hidroponik. Yogyakarta: CV. ANDI OFFSET.

Syafrudin. 2004, "Pengelolaan sampah berbasis masyarakat". Diskusi interaktif pengelolaan sampah terpadu. Prosiding, Program Magister Ilmu Lingkungan Universitas Diponegoro, Semarang. 